\title{
A AÇÃO CIVIL PÚBLICA COMO INSTRUMENTO DE COMBATE À CORRUPÇÃO NO ESTADO DEMOCRÁTICO DE DIREITO
}

\author{
Paulo HenRique Blasi*
}

Dentre os importantes temas apresentados e debatidos no I Congresso Brasileiro de Direito Público realizado em São Paulo, no mês de abril último, despertou especial atenção aquele relativo ao "combate à corrupção no Estado Democrático de Direito".

As notícias diariamente divulgadas pela imprensa nacional e estrangeira, dão conta do seríssimo problema gerado pelas ações de responsáveis pela coisa pública. São escândalos inomináveis, envolvendo políticos, administradores, poderosas empresas que se tomam rotina. A discussão sobre moralidade e probidade, nunca esteve tão em evidência.

O teor das informações veiculadas preocupa a sociedade como um todo. A violência, o tráfico de drogas, os assaltos, a pobreza, os profundos desajustes sociais, o desemprego, a par da divulgação de fatos sobre desvios éticos de autoridades públicas no desempenho de suas funções, estão a causar quase uma "neurose coletiva".

O extraordinário avanço e a sofisticação dos meios de comunicação acabaram por desnudar as atividades públicas ou privadas. Somos testemunhas oculares e instantâneas do que se passa em todo o mundo. As informações, quais furacão arrasador, invadem a choupana do pobre ou o palácio do rico com a mesma intensidade. A modificação dos costumes e a nova visão do mundo, em decorrência.

Daí a importância do tema debatido no I Congresso Brasileiro de Direito Público, condensado na exposição dos integrantes do Painel: Professora Lúcia Valle Figueiredo (visão geral do problema, acentuando a conduta dos Administradores Públicos); Professor Adilson Abreu Dallari (a Lei de Improbidade Administrativa); Conselheiro Dr. João Fedder, Professora Flávia Piovesan e o autor deste estudo, analisando aspectos do controle da moralidade administrativa através do Tribunal de Contas, da ação popular e da ação civil pública.

* Advogado e Professor da Universidade Federal de Santa Catarina. 
A intensa divulgação dos fatos e a facilidade de acesso aos mesmos, conduz à impressão de que o assunto (conduta ética na política), é um fenômeno da atualidade. Um "sinal dos tempos" em que vivemos.

Uma análise retrospectiva, ainda que perfunctória, mostra-nos que a preocupação sobre a conduta do homem em sociedade perpassa os tempos. Observa, com propriedade PROSPER WEIL (O Direito Administrativo, Livraria Almedina, 1977), estar na "natureza das coisas que um governante acredite, de boa fé, que está investido do poder de decidir discricionariamente acerca do conteúdo e das exigências de interesse geral. É preciso que ele faça um esforço sobre si mesmo para se considerar como obrigado a manter se na esteira de um direito que lhe impõe certas condutas $e$ lhe proibe outras". Embora entenda o autor um fato natural o acreditar o governante que os atos que pratica - em razão da investidura que lhe foi conferida - o são para atendimento do interesse público, a verdade é que, muitos deles, por desvio de formação, por falta de discernimento ou por má fé, utilizam-se das posições a que foram guindados, para satisfação de outros interesses, que não os de caráter geral.

Não se pode olvidar, com WEIL, que as lições da história nos mostram que "a conquista do Estado pelo direito é relativamente recente e não está ainda terminada em toda a parte".

No ano 533 da era Cristã (há cerca de 1.500 anos, portanto), ao editar as "INSTITUTAS", que juntamente com o Digesto, Código e Novellas passaram a constituir o que se chamou modernamente de "Corpus Juris Civilis", o Imperador Justiniano dedicou-as "à mocidade que estuda as leis". No LIVRO I, TITULO I, ao tratar do "DIREITO E DA JUSTIÇA", após definir a "jurisprudência" e acentuar a necessidade de facilitar o acesso às leis $\left(\$ \S 1^{\circ}\right.$ e $\left.2^{\circ}\right)$, enfatizava: "os preceitos do direito são estes: viver honestamente, não ofender a outrem dar a cada um o que $\epsilon$ seu" ( $\$ 3^{\circ}-$ "Honeste vivere, alterum non laedere, jus suum cuique tribuere"). Acentua o tradutor que "viver honestamente é o primeiro fundamento da cultura jurídica. As leis também se inspiram em motivos de ordem moral. ("Institutas do Imperador Justiniano" - obra traduzida e comparada por SPENCER VAMPRE, Lente de Direito Romano da USP - 1915).

Inobstante as lições mais do que milenares de que o "viver honestamente", constitui-se em preceito fundamental do direito, e, portanto do equilibrio e da harmonia da vida em sociedade, a grande verdade é que, sob o pretexto de preservar as razões de Estado, a tradição do segredo passou a ser justificada como único instrumento capaz de resguardar o interesse público. Mas, atrás do segredo, escondiam-se como escondem-se, muitas vezes, atos que "não podem" ser divulgados. Daí a renitência em quebrá-lo.

Em recente obra ("La Transparence Administrative") seus autores: Bruno Lasserre, Noëlle Lenoir e Bernard Stirn, ao fazerem um interessante estudo sobre a matéria, mostram a divergência de posições entre NECKER e CHAMPAGNY. $O$ primeiro, em seu "Tratado da Administração das Finanças da França", publicado em 1784, afirmava que a majestade do Príncipe não seria afetada se desse conhecimento ao público do "motivo" de seus atos. Já o segundo, poucos anos depois, como 
Ministro do Interior do Império, em circular dirigida aos Prefeitos, era enfático: "Não se deve jamais falar aos jornalistas".

A transposição para a realidade brasileira mostra que apesar da inserção no texto da Constituição de 1988 dos princípios da publicidade e da moralidade, apesar dos avanços extraordinários da ciência e da técnica no que diz respeito à transparência da ação administrativa, apesar dos instrumentos de controle instituídos em nível constitucional, apesar das sanções previstas, o problema continua latente e a desafiar a tudo e a todos.

Dentre os instrumentos constitucionais de controle da atividade administrativa, coube-nos abordar alguns aspectos da ação civil pública.

Indaga-se: por que a projeção e o relevo assumido hoje pela ação civil pública?

Substancialmente pela atuação do Ministério Público, dada a legitimidade ativa que lhe é deferida para deflagrar a ação. Mas se o órgão existe há tanto tempo, por que somente agora seu realce?

A Constituição de 1934, abriu, pela vez primeira, no Capítulo (VI) - "Dos Órgãos de Cooperação nas Atividades Governamentais" — uma "secção “(I), referente ao Ministério Público, cujo chefe, o Procurador-Geral da República, era de livre indicação do Presidente da República, com aprovação do Senado Federal. À lei local competia organizar o Ministério Público nos Estados. Na Carta de 1937, pelo seu caráter ditatorial, o Ministério Público perdeu seu "status" constitucional, tendo a ele sido destinado um artigo (99) no "capítulo" do "Supremo Tribunal Federal", tratando da escolha do Procurador-Geral da República. A subordinação ao Executivo ficou patenteada, pois os respectivos Chefes, tanto no nível Federal como Estadual, passaram a ser nomeados por livre escolha do Presidente da República ou dos Interventores Estaduais. A autonomia mesmo na esfera penal tornou-se relativa, pois era comum a transferência de Promotores cuja atuação pudesse desagradar aos detentores do poder.

A Constituição de 1946 conferiu destaque maior ao Ministério Público, através de um "Título" especial (III - Arts. 125/128). O Chefe do Ministério Público era nomeado pelo Presidente da República, "depois de aprovada a escolha pelo Senado Federal". Era, contudo, "demissivel ad nutum". Cabia ao Ministério Público a "representação da União" em Juízo (parágrafo único do artigo 126). Estes dois aspectos mostram a relatividade da independência do órgão do "parquet" frente ao Estado, uma vez que, seu chefe além de "demissível ad nutum", por força de comando constitucional, era o representante da União em Juízo. Nos Estados o fenômeno era o mesmo, pois às "leis locais" competia a organização do Ministério Público. Os Procuradores Gerais (Chefes do Ministério Público) eram de livre nomeação dos Governadores, sem que, quanto a eles, houvesse necessidade de audiência prévia do Poder Legislativo. Em muitos Estados, o Procurador Geral exercia simultaneamente as funções de Chefia do Ministério Público e de representante e defensor maior do Estado. Tais funçōes, por serem muitas vezes antagônicas, geravam crises que afetavam, sobremodo, a autonomia do Órgão.

A Carta de 1967 com redação quase igual à de 46, tratou do Ministério Público no "Capítulo VIII - Do Poder Judiciário", abrindo-lhe seção especial (IX). Manteve, no plano federal, a aprovação do Senado, para a escolha do Procurador-Geral 
da República. Já a Emenda Constitucional nº 01/69, editada pelos Comandantes Militares, além de transferir o Ministério Público (Seção IX) para o capítulo "Do Poder Executivo" (VI) retirou do Senado a prerrogativa de aprovar o nome do Chefe do Ministério Público Federal, que passou a ser exclusiva do Presidente da República. Segundo o texto autoritário, os "membros do "Parquet" não podiam ser removidos, a "não ser mediante representação do Procurador-Geral, "com fundamento em conveniência do serviço". A relatividade da autonomia do órgão ficou patente. A representação da União em juízo continuou com o Ministério Público, inclusive nas comarcas do interior ( $\$ 2^{\circ}$ do art. 95 ).

Fácil compreender o paradoxo gerado pela duplicidade de atribuições do Ministério Público (por um lado, fiscal da Lei e fiel da sua execução; e, por outro "representante" e, portanto, defensor constitucional do Estado. O conflito era patente.

A autonomia e a independência do Ministério Público somente foram atingidas em sua plenitude com a Constituição de 1988, que, além de fixar mandato para o exercício do cargo de Procurador-Geral, determinou que sua escolha fosse feita dentre integrantes da carreira, outorgando a seus membros as garantias que, constitucionalmente, somente eram previstas para os magistrados (vitaliciedade, inamovibilidade e irredutibilidade de vencimentos).

No que tange à ação civil pública, é oportuno lembrar que a lei de sua regência veio a lume ainda na vigência do regime anterior (Lei 7.347/85). Dita lei, no entanto, visou disciplinar a "ação civil pública de responsabilidade civil por danos causados ao meio ambiente, ao consumidor, a bens e direitos de valor artístico, estético, histórico, turístico e paisagístico". A expressão que incluía "qualquer outro interesse difuso" “ (inc. IV do Art. $1^{\circ}$ ) foi vetada, sob alegação de ser "amplíssima e imprecisa sua abrangência". Através da Lei 8.078/90 (Código de Defesa do Consumidor art. 110), foi incluído, no Artigo $1^{\circ}$ da Lei 7.347/85, o item IV, com redação similar àquela vetada, isto é, colocando na esfera de abrangência da ação civil pública, a responsabilidade por danos causados "a qualquer interesse difuso ou coletivo".

Dadas as divergências no campo doutrinário e jurisprudencial a respeito de direitos difusos, coletivos ou transindividuais, o próprio Código de Defesa do Consumidor encarregou-se de defini-los: tratar de:

“Art. 81 - Parágrafo Único: A defesa coletiva será exercida quando se

I-interesses ou direito difusos, assim entendidos, para efeito deste Código, os transindividuais, de natureza indivisivel, de que sejam titulares pessoas indeterminadas e ligadas por circunstâncias de fato;

II - interesses ou direito coletivos, assim entendidos, para efeito deste Código, os transindividuais de natureza indivisiveis de que seja titular grupo ou classe de pessoas ligadas entre si com a parte contrária por uma relação jurídica de base;

III - interesses ou direitos individuais homogêneos, assim entendidos os decorrentes de origem comum." 
Embora a alteração introduzida pelo Código de Defesa do Consumidor, no pertinente à defesa de qualquer interesse difuso ou coletivo, a ação civil pública passou a projetar-se como instrumento de defesa da probidade administrativa, a partir da vigência da Lei 8.429 (03/06/92), que, por sua natureza substantiva, definiu infrações e estipulou as respectivas penas aplicáveis. É que a lei disciplinadora da ação civil pública, sendo unicamente adjetiva (processual), dependia, no tocante ao controle da moralidade pública, de lei específica. Acentuando este aspecto, Hely Lopes Meirelles, em comentários à Lei 7.347/85, aduzia: "a condenação deve basear-se em disposição de alguma norma substantiva de direito material da União, do Estado ou Município que tipifique a infração, que dever ser apreciada e punida pelo judiciário, independentemente de qualquer outra sanção administrativa ou penal, em que incida o infrator" ' (Mandado de Segurança, Ação Popular e Ação Civil Pública, ED RT 1989, p. 120).

Com a independência e as prerrogativas insculpidas na Constituição de 1988, o Ministério Público passou a exercer papel preponderante no controle da moralidade administrativa. Daí a divulgação diária de notícias sobre ações promovidas com vistas à responsabilização de agentes públicos. Também a pessoa jurídica interessada tem legitimação para interpor ação de responsabilidade, com fulcro na lei que rege a ação civil pública. A prática tem demonstrado, contudo, que as mais das vezes, essas propõem a ação, quando há mudança de Governo, assumindo partido adversário do que se encontrava no poder. Em razão disso, as questões (autoria da pessoa jurídica interessada) assumem, mais aspecto de retaliação política do que de defesa da probidade administrativa.

Qualquer pessoa pode e o funcionário público deve informar ao Ministério Público sobre fatos que possibilitem a intentação da ACP. Também os Juízes e Tribunais devem remeter peças ao órgão, quando tiverem conhecimento de fatos que ensejem a propositura da ação civil pública.

Paralelamente ao exercício da função institucional de promoção da ação civil pública, foi constitucionalizada a legitimação do Ministério Público para instaurar inquérito civil, com a finalidade de colher elementos para a instauração ou não da ação. Entendendo o órgão inviável a intentação da ação, poderá pedir arquivamento do inquérito, que, no entanto, dependerá de decisão do Conselho Superior.

Sobre o "inquérito civil público" como instrumento inovador, vale lembrar manifestação do hoje Ministro José Celso de Mello Filho, quando assessor do Gabinete Civil da Presidência da República, sobre o projeto de que resultou a Lei 7.347/85:

"O projeto de lei que dispõe sobre a ação civil pública, institui, de modo inovador, a figura do inquérito civil. Trata-se de procedimento meramente administrativo, de caráter pré-processual, que se realiza extrajudicialmente, $O$ inquérito civil, de instauração facultativa, desempenha relevante função instrumental. Constitui meio destinado a coligir provas e quaisquer outros elementos de convicção, que possam fundamentar a atuação processual do MP. O inquérito civil, em suma, configura um procedimento preparatório destinado a viabilizar o exercício responsável da ação civil pública. Com ele, frustra-se a 
possibilidade, sempre eventual, de instauração de lides temerárias. A instauração do inquérito civil não obrigará o MP ao ajuizamento da ação, desde que lhe pareçam insuficientes os elementos de conviç̧ão coligidos" (HELY LOPES MEIRELLES, op. cit. p. 118).

A participação do Ministério Público, em ação civil pública, quando intentada por qualquer outra entidade legitimada, é obrigatória.

Não há dúvida que, atualmente, a ação civil pública constitui-se em instrumento valioso de combate à corrupção, que, infelizmente, qual praga daninha, está disseminada em todo o país. Recentes notícias veiculadas pela imprensa informam que só no Estado de São tramitavam, em março último, 532 ações contra Prefeitos por improbidade administrativa. Em todos os Estados da Federação o fenômeno é o mesmo. A situação é alarmante e desafia a todos, tanto mais quando nos apercebemos que o fenômeno é universal.

Todos clamam pela necessidade de que se ponha um fim a situação tão calamitosa. Mais do que nunca faz-se presente a necessidade de fortificar-se a educação, sobretudo a educação política e o exercício da cidadania, para que não se confundam instituições fundamentais à existência da democracia, com os desvios de alguns de seus membros. Toda a generalização gera injustiças. Se existem juízes, administradores e representantes legislativos que são desonestos, nem por isto vamos macular toda a Instituição e seus integrantes. Punir os ímprobos, sim, e cada vez com maior rigor, mas sem as influências do sensacionalismo barato que, muitas vezes, desvirtuando acontecimentos, na ânsia da publicidade, cometem injustiças irreparáveis. A calma e a ponderação, aliadas à vontade enérgica, são elementos substanciais a justificar os atos humanos, pois só os irracionais agem movidos exclusivamente pelos instintos.

O Ministério Público, como guardião constitucional da probidade, deve agir com severidade, porém com prudência e ponderação, a fim de que se preserve sua autoridade e independência.

No que tange aos desvios que são constatados nas Prefeituras Municipais, parece-nos que grande parte deles derivam-se da falta de orientação aos Prefeitos. A pletora de atos Municipais investigados pelos Tribunais de Contas, pelas Comissões Parlamentares de Inquérito, pelo Ministério Público, estão a oferecer matéria suficiente para que possam ser editados programas com facilidade de acesso através dos excepcionais meios oferecidos pela tecnologia moderna, oferecendo subsídios a respeito de procedimentos a serem seguidos pelos administradores. Esta seria uma medida preventiva de real valor. Conhecedor das responsabilidades e esclarecido das dúvidas a respeito de qualquer ato, quem errar não poderá fugir aos rigores das sanções aplicáveis.

Ante o quadro em que vivemos, quando a indignação toma conta do País pela sucessão de fatos que denigrem nossa imagem e comprometem nosso futuro, dando maus exemplos a nossos descendentes, faz-se necessária uma cruzada permanente pela ética na política, a fim de que não tenhamos que repetir a sentença de Ruy: $D e$ tanto ver triunfar as nulidades, de tanto ver crescer a impunidade, de tanto verem os maus e desonestos ocuparem posições de destaque, e malbaratarem o patrimônio público, o homem ri da honra e tem vergonha de ser honesto. 